\title{
Re-Structuring Preservice Teacher Education: Introducing the School-Community Integrated Learning (SCIL) Pathway
}

\author{
Sue Hudson ${ }^{1} \&$ Peter Hudson $^{1}$ \\ ${ }^{1}$ Faculty of Education, Queensland University of Technology, Queensland, Australia \\ Correspondence: Sue Hudson, Faculty of Education, Queensland University of Technology, Tallon Street, \\ Caboolture, Queensland, Australia. Tel: 61-7-3138-3345. E-mail: sm.hudson@qut.edu.au
}

Received: October 21, 2012

Accepted: October 30, $2012 \quad$ Online Published: January 9, 2013

doi:10.5539/jel.v2n1p9

URL: http://dx.doi.org/10.5539/jel.v2n1p9

\begin{abstract}
Reviews into teacher education call for new models that develop preservice teachers' practical knowledge and skills. The study involved 9 mentor teachers and 14 mentees (final-year preservice teachers) working in a new teacher education model, the School-Community Integrated Learning (SCIL) pathway, and analysed data from a Likert survey with extended written responses. Despite minor discrepancies between mentors and mentees' agreement on the experiences mentees received during the SCIL pathway, findings indicated $100 \%$ agreement on 8 of the 27 survey items for addressing the practicalities of learning how to teach. Indeed, 70\% or more mentees agreed that they had a range of experiences across the five categories (i.e., personal-professional skill development, understandings of system requirements, teaching practices, student behaviour and reflective practices). Written responses outlined that preservice teachers began to recognise the breadth of teachers' roles and responsibilities. The SCIL pathway was noted as a cost-effective model that assisted to fill some gaps indicated within general practicum and internship models.
\end{abstract}

Keywords: preservice teachers, university-school partnerships, mentoring

\section{Introduction}

This study investigates an innovative teacher education program facilitated at one Australian university titled the "School-Community Integrated Learning" (SCIL) pathway. As a result of university-school engagement with a reference group of educators, including school executives (see Hudson \& Hudson, 2006), it was decided that the Bachelor of Education (primary) degree at this small university campus would incorporate a SCIL pathway for final-year preservice teachers to advance their theory-practice connections and build experiences generally not noted in practicum and internship models.

\subsection{Relevant Literature}

For years, educators (e.g., Lunenberg \& Korthagen, 2009; Wideen, Mayer-Smith, \& Moon, 1998) concur that graduates have difficulty applying university theory to classroom practice. Yet, "the perennial challenges of integrating theory with practice faced by existing teacher education models (Putnam \& Borko, 2000) suggest a change in thinking about the structure and focus of preservice practica" (Moore, 2003, p. 41). It is emphasised strongly that a quality practicum would integrate theory and practice at progressive stages of development through strong university-school partnerships to provide "diverse experiences in a range of school contexts and with a variety of students" (HRSCEVT, 2007, p. 74). However, these notions of connecting theory to practice may not address all the issues early-career teachers (preservice and beginning) have expressed. For instance, behaviour management is a key issue for early-career teachers, and although preservice teachers are educated on behaviourist theories such as Glasser's (1992) choice theory, problems around behaviour management continue to occur in the practicum (e.g., Putman, 2009).

Traditional models of preservice teacher education are noted as university coursework "with block practicum placements in schools occurring on either side of [the] university semester" (Graham \& Thornley, 2000, p. 235). Traditional models are also recognised as an "opportunity to apply previously learned theories"; however the "theory-into-practice view of teacher education is increasingly being challenged for its many limitations and inadequacies" (Korthagen, Loughran, \& Russell, 2006, p. 1021). Moore (2003) points to the development of pedagogical practices and possibly focusing on gestalts (see Korthagen \& Kessels, 1999) for preservice teachers 
to transfer theoretical learning into their own classroom practices. In the context of professional school experiences, well-formed gestalts (i.e., "conglomerates of cognitive, emotional, and motivational aspects") assist in working effectively within an environment (Lunenberg \& Korthagen, 2009, p. 231). It is claimed by Korthagen (2009) that preservice teachers need to "gain more experiences that are suited to developing adequate Gestalts"; these experiences include one-on-one tutoring, small group work, and other forms of scaffolded development (p. 12).

Emerging political issues impact on teacher education reviews, such as education ratings from the National Assessment Program in Literacy and Numeracy (NAPLAN) results. For instance, Queensland students in years 5 and 7 scored below the national average in reading and numeracy (Welford, 2008); consequently the Education Green Paper (Queensland Government, 2010) highlights the need for enhanced teacher and preservice teacher development, which was further supported by a government review into teaching and teacher education (see Masters, 2009). To address these issues, Masters advocates that early-career teachers "should be familiar with, and be beginning to develop, a repertoire of evidence-based teaching strategies (e.g., for the teaching of reading)" (p. 9, parenthesis in original). Despite preservice teachers being educated on the teaching of literacy and numeracy, connecting theory to practice may be impeded by traditional models of teacher education. It is further reported that practicum experiences are variable and compounded by the fact that "many universities reported that they are having serious difficulties in finding a sufficient number of placements for their students" (HRSCEVT, 2007, p. 70). In addition, practicum timings and durations are dependent upon the university semesters, university coursework, and the school calendar.

School experiences are intended to provide preservice teachers with opportunities to explore, practice, reflect, and refine pedagogical concepts taught at university (Brady, 2000; Korthagen \& Kessels, 1999). The benefits of school experiences for preservice teachers are well recorded (Hodge, Davis, Woodward, \& Sherrill, 2002; Smith \& Snoek, 1996). Preservice teachers purport that school experiences provide a real-world context and deeper understandings about teaching and learning (Hudson, 2009). The focus on teacher education returns to facilitating school experiences that connect theory to practice for preservice teachers (Brady, 2000; Moore, 2003). It seems logical to suggest that preservice teachers have individual belief systems and assumptions that are formed during their teacher preparation program (Deng, 2004), and that theory-practice connections require developing pedagogical knowledge within contextual circumstances to elevate learning towards professional teaching levels. Providing preservice teachers with a range of school experience within competing university coursework schedules and devising cost-effective models to facilitate theory-practice connections present as challenges for universities. This study aimed to investigate the School-Community Integrated Learning (SCIL) pathway as a cost-effective extension model to existing practicum and internship models. In particular, it explores mentors' and mentees' perceptions about the SCIL pathway in relation to how it contributes to preservice teacher development.

\section{Method}

\subsection{Context for the Study}

This study is set in a low socio-economic community where only $25 \%$ of school students make the transition to university. Through an Australian Government grant, the Teacher Education Done Differently (TEDD) project was underpinned by the notion of reciprocity where all aspects of the project were required to demonstrate "benefits for all" (i.e., the schools, students, preservice teachers, teachers, lecturers and university). One arm of the project consisted of the integration of Applied Learning Experiences (ALEs) into the Bachelor of Education (BEd primary) program offered at the campus (see www.tedd.net.au; Table 1).

In 2009, the School Community Integrated Learning (SCIL) pathway was developed and became an additional initiative to the existing TEDD project activities. Extending the experiences of the Ed Start program (Table 1), the SCIL pathway was designed for final-year preservice teachers to be placed in local Queensland schools during the student free days in January and volunteer three days per week until university commenced. Once university started, preservice teachers attended university classes and visited their school one day per week, continuing at the school to complete two final-year practicum experiences and a four-week internship. It was recommended that preservice teachers change their grade level and teacher for the second practicum experience to ensure a variety of classroom experiences was achieved. It is important to note that because of work and family commitments, the SCIL pathway was presented as a voluntary option for final-year preservice teachers and not a compulsory part of the BEd primary program. Table 2 outlines the activities and timeframes of the SCIL pathway. 
Table 1. Applied Learning Experiences (ALEs)

\begin{tabular}{|c|c|c|c|c|}
\hline Name of ALE & \multicolumn{4}{|c|}{ Description of the ALE } \\
\hline Move It, Use It & \multicolumn{4}{|c|}{$\begin{array}{l}\text { Small groups of first-year preservice teachers design and deliver physical education } \\
\text { activities to groups of school students at a school }\end{array}$} \\
\hline Art Works & \multicolumn{4}{|c|}{$\begin{array}{l}\text { Second-year preservice teachers design and deliver art activities to groups of school } \\
\text { students who visit the university campus }\end{array}$} \\
\hline Science with kids & \multicolumn{4}{|c|}{$\begin{array}{l}\text { Pairs of second-year preservice teachers design and deliver science activities to } \\
\text { groups of school students who visit the university campus }\end{array}$} \\
\hline Reading Squadron & \multicolumn{4}{|c|}{$\begin{array}{l}\text { Third-year preservice teachers work one-on-one to assist with reading to school } \\
\text { students who are identified as requiring reading support }\end{array}$} \\
\hline BGR8 & \multicolumn{4}{|c|}{$\begin{array}{l}\text { Pairs of final-year preservice teachers design and deliver a gifted and talented mini } \\
\text { unit to a student, identified by the school as gifted and talented }\end{array}$} \\
\hline Ed Start & \multicolumn{4}{|c|}{$\begin{array}{l}\text { Preservice teachers are placed in their schools six weeks prior to the commencement } \\
\text { of each practicum (one day per week) }\end{array}$} \\
\hline Over the Hill & \multicolumn{4}{|c|}{$\begin{array}{l}\text { Preservice teachers participate in a fully-funded six-day rural and remote teaching } \\
\text { experience }\end{array}$} \\
\hline \multicolumn{5}{|c|}{ vities and timeframes } \\
\hline Semester 1 & & & Semester 2 & \\
\hline Late January / February & February - May & May - June & July / August & September / November \\
\hline $\begin{array}{l}\text { Visit school three days } \\
\text { per week }\end{array}$ & $\begin{array}{l}\text { Attend university } \\
\text { and visit school } \\
\text { one day per week }\end{array}$ & $\begin{array}{l}\text { Complete four } \\
\text { week block } \\
\text { practicum }\end{array}$ & $\begin{array}{l}\text { Attend university } \\
\text { and visit school } \\
\text { one day per week }\end{array}$ & $\begin{array}{l}\text { Complete final practicum } \\
\text { and internship in the } \\
\text { same school (eight weeks } \\
\text { in total) }\end{array}$ \\
\hline
\end{tabular}

After stakeholders' approval, the SCIL pathway became an integral part of the TEDD project. Further discussions were held to ascertain the roles and responsibilities of those involved and how the SCIL preservice teachers may participate in the school. Funding to pay mentor teachers was available for the two final practicum experiences but not for the voluntary SCIL weekly visits; therefore it was decided that the SCIL pathway would not require any paperwork or reports for the teachers to complete. Furthermore, mentor teachers could volunteer to have SCIL pathway preservice teachers without pressure from school or university staff. The workloads of the preservice teachers needed to be considered as once university commenced they would need to meet the requirements of their coursework. Thus, it was decided the SCIL pathway would be a non-teaching experience with preservice teachers participating in suggested activities outlined to the mentor teachers through university documents. The types of activities included: preservice teacher observations of their allocated mentor teacher and other teachers in the school; getting to know the students and daily routines; assisting in small group activities; visiting special education units and specialist teachers; participating in playground duty and staff meetings; assisting with sports and swimming carnivals; and becoming familiar with school policies and procedures.

As with the entire TEDD project, the SCIL pathway was viewed as a partnership arrangement between the university and schools. It was therefore essential that those involved had a clear picture of how the preservice teachers' progress would be monitored and how the school and mentor teachers would be supported. Information packages were sent to volunteer mentor teachers and information sessions were held for interested preservice teachers. Once all the information was collated, the preservice teacher placements were completed so they knew their allocated classes and mentor teachers before the conclusion of the Queensland school year and in readiness for the first visits in late January. The university coordinator stayed in regular contact with the school site coordinators to ensure the preservice teachers were fulfilling their SCIL requirements and attending their allocated schools. Each school site coordinator stayed in contact with their mentor teachers. The university coordinator visited each school to oversee the working of the SCIL pathway and discuss the progress of the preservice teachers. 


\subsection{Participant Demographics}

The study participants included 14 final-year preservice teachers (mentees) and 9 mentors. The mentees (4 males, 10 females) were surveyed in which $57 \%$ were under the age of 22 years and $43 \%$ were mature-aged students. Their teaching classes varied from Preparation (around 5 years of age) through to Year 7 (about 12 years old). There were also 9 mentor teachers (all female) aged 30 years or older surveyed with one who had taught in the primary school between 6-10 years and the rest had taught 11 years or more. One teacher had mentored between 1-5 mentees while the rest had mentored 6 or more mentees (two in excess of 15 mentees). All mentors strongly agreed that the SCIL pathway had benefited the mentees (with one unspecified). These 9 mentors had mentored 9 of the 14 mentees (final-year preservice teachers) in this study (five mentors did not participate in this study). Two mentors were also the site coordinators (i.e., mentors $8 \& 9$ monitored the mentoring at their schools). Site coordinators oversee the mentoring of preservice teachers within a particular school.

\subsection{Sampling Procedure}

This small-scale study used a Likert survey with extended written responses to understand the impact of the School-Community Integrated Learning (SCIL) pathway on final-year preservice teachers. The survey drew from other works (e.g., Hudson \& Hudson, 2011; Hudson \& Hudson, 2012) as a basis for survey item construction and adhered to survey development guidance for internal construct validity (Creswell, 2012). For example, guidelines for survey development include avoiding questions that are: unclear, double-barrelled, lengthy, negatively skewed, unbalanced response options, mismatched between questions and answers, technical (or with jargon), and not applicable to all participants (Creswell, 2012, pp. 389-390). The survey items were collated under broad categories (i.e., personal-professional skill development, understandings of system requirements, teaching practices, student behaviour and reflective practices). For instance, under the category "personal-professional skill development" there were six items constructed around: enthusiasm for teaching, communication with students, confidence as a teacher, professional relationships with colleagues, understanding of teacher's relationships with parents, and understanding the teacher's role. Respondents used a five part Likert scale ranging from strongly disagree to strongly agree (uncertain in the middle) to respond to each item, which was adjusted only to gauge responses for the two groups of participants (mentors and mentees). To illustrate, the mentor survey had "During the SCIL Pathway program, I believe I provided opportunities for the preservice teacher to develop strategies for solving teaching problems" while in mirror formatting the mentee survey had "During the SCIL Pathway program, I believe my mentor provided opportunities for me to develop strategies for solving teaching problems". Descriptive statistics (percentages, means, and standard deviations) were collated for analytical purposes.

The written responses were transcribed by an experienced researcher with a $\mathrm{PhD}$. The researchers collated the transcribed text into themes to describe the phenomenon being studied. Coding for themes was a process that "makes sense out of text data, divides it into text or image segments, labels the segments, examines codes for overlap and redundancy, and collapses these codes into themes" (Creswell, 2012, p. 618). Creswell also suggests developing a hierarchical diagram that "visually represents themes" in which findings can be presented through a narrative discussion (p. 254).

\section{Results and Discussion}

\subsection{Survey Responses}

Mentors $(n=9)$ and mentees $(n=14)$ were surveyed across the five categories (personal-professional skill development, understandings of system requirements, teaching practices, student behaviour and reflective practices) to understand the degree the SCIL pathway had contributed to the final-year preservice teachers on each of these items. All mentors and nearly all mentees agreed or strongly agreed that the SCIL pathway assisted the preservice teachers' personal-professional skill development. All agreed that it facilitated communication with students, allowed for the development of professional relationships with colleagues and parents, and assisted in understanding the teacher's role (Table 3). Schools are "aware of the importance of building relationships with parents and the community" (Masters, 2009, p. 55). As reviews highlight beginning teachers' abilities "to communicate with parents" as a consistent concern for teacher education (HRSCEVT, 2007, p. 8), data in this study showed that SCIL presented opportunities to understand the parent-teacher relationship (Table 4). Similarly, all mentors agreed that the SCIL pathway helped final-year preservice teachers to understand the education system requirements. Indeed, all mentors and mentees agreed that it helped for understanding how to create a supportive learning environment, the roles and responsibilities of staff, and the school practices and policies (Table 5). 
Table 3. Personal-professional skill development

\begin{tabular}{|c|c|c|c|c|c|c|}
\hline \multirow[t]{2}{*}{ Practices/attributes } & \multicolumn{3}{|c|}{ Mentors } & \multicolumn{3}{|c|}{ Mentees } \\
\hline & $\% *$ & $M$ & $S D$ & $\% *$ & $M$ & $S D$ \\
\hline Enthusiasm for teaching & 100 & 4.89 & 0.33 & 86 & 4.64 & 0.75 \\
\hline Communication with students & 100 & 4.78 & 0.44 & 100 & 4.64 & 0.50 \\
\hline Confidence as a teacher & 100 & 4.56 & 0.53 & 83 & 4.43 & 0.65 \\
\hline Professional relationships with colleagues & 100 & 4.78 & 0.44 & 100 & 4.64 & 0.50 \\
\hline Understanding parent-teacher relationships & 100 & 4.33 & 0.50 & 83 & 4.50 & 0.86 \\
\hline Understanding teacher's role & 100 & 4.78 & 0.44 & 100 & 4.79 & 0.43 \\
\hline
\end{tabular}

* Percentage of participants who agreed or strongly agreed.

Table 4. Understandings of system requirements

\begin{tabular}{|c|c|c|c|c|c|c|}
\hline \multirow[t]{2}{*}{ Practices } & \multicolumn{3}{|c|}{ Mentors } & \multicolumn{3}{|c|}{ Mentees } \\
\hline & $\%$ & $M$ & $S D$ & $\%$ & $M$ & $S D$ \\
\hline Creating a supportive learning environment & 100 & 4.78 & 0.44 & 100 & 4.64 & 0.50 \\
\hline Roles and responsibilities of school staff & 100 & 4.67 & 0.50 & 100 & 4.57 & 0.51 \\
\hline School practices and policies & 100 & 4.56 & 0.53 & 100 & 4.64 & 0.50 \\
\hline Whole school planning & 100 & 4.56 & 0.53 & 71 & 4.07 & 1.02 \\
\hline Using school aims & 100 & 4.33 & 0.50 & 93 & 4.64 & 0.63 \\
\hline
\end{tabular}

The majority of mentors and mentees agreed that the SCIL pathway provided an understanding for teaching practices shown in Table 5. There were two practices where all mentors and mentees agreed on, namely, understanding the educational language for teaching and setting up the classroom for the future. Surprisingly, there was $100 \%$ agreement from mentees that the SCIL pathway facilitated monitoring of students' activities compared with the mentors' agreement (89\%). As a possible way to negate beginning teachers concerns around assessment pressures (Certo, 2006), it was indicated that $89 \%$ of mentors and $79 \%$ of mentees agreed the SCIL pathway provided more understanding about strategies for assessing students' learning. Importantly, beginning teachers report that they need to understand how to set up a classroom from day one of the school year (e.g., HRSCEVT, 2007), for which $100 \%$ of mentors and mentees in this study suggested they have gained such understandings.

Table 5. Teaching practices

\begin{tabular}{|c|c|c|c|c|c|c|}
\hline \multirow{2}{*}{ Practices } & \multicolumn{3}{|c|}{ Mentors } & \multicolumn{3}{|c|}{ Mentees } \\
\hline & $\%$ & $M$ & $S D$ & $\%$ & $M$ & $S D$ \\
\hline Educational language for teaching & 100 & 4.56 & 0.53 & 100 & 4.64 & 0.50 \\
\hline Appropriate educational challenges & 100 & 4.89 & 0.33 & 86 & 4.29 & 0.91 \\
\hline Ideas for effective hands-on activities & 100 & 4.56 & 0.53 & 79 & 4.14 & 0.77 \\
\hline Setting up a classroom for the future & 100 & 4.78 & 0.44 & 100 & 4.57 & 0.51 \\
\hline Content knowledge & 89 & 4.33 & 0.71 & 93 & 4.43 & 0.65 \\
\hline Planning in teams for teaching & 100 & 4.56 & 0.53 & 86 & 4.57 & 0.94 \\
\hline Strategies for solving teaching problems & 100 & 4.33 & 0.50 & 79 & 4.14 & 0.77 \\
\hline Understanding of well-designed activities & 100 & 4.33 & 0.50 & 79 & 4.29 & 0.83 \\
\hline Strategies for assessing student's learning & 89 & 4.22 & 0.67 & 79 & 4.07 & 0.92 \\
\hline Monitoring of students' activities & 89 & 4.00 & 0.87 & 100 & 4.43 & 0.51 \\
\hline
\end{tabular}


The next two categories (understanding student behaviour and reflective practices) showed that the majority of mentors and mentees agreed that the SCIL pathway assisted the mentee in all items (Table 6). There were two main discrepancies where $14 \%$ more mentors than mentees agreed the program allowed for understanding of effective classroom management and $11 \%$ more mentees claimed it provided ways to improve teaching. These two responses may be interpreted through the respondents' perspectives. For instance, mentees were observing the mentor teachers during classroom management; consequently mentors were likely to report that they were effective in this area. However, it could also occur as a result of five mentors not participating in this study. Nevertheless, there are consistent concerns for teacher education around dealing "adequately with classroom management issues" (HRSCEVT, 2007, p. 8) and beginning teachers have "struggles with classroom management" (Blair, 2008, p. 99); yet the SCIL pathway seemed to provide further understandings about effective classroom management for these pre-beginning teachers (Table 6).

Table 6. Working with student behaviour and reflective practices

\begin{tabular}{|c|c|c|c|c|c|c|}
\hline \multirow[t]{2}{*}{ Practices } & \multicolumn{3}{|c|}{ Mentors } & \multicolumn{3}{|c|}{ Mentees } \\
\hline & $\%$ & $M$ & $S D$ & $\%$ & $M$ & $S D$ \\
\hline Effective classroom management & 100 & 4.56 & 0.53 & 86 & 4.29 & 0.73 \\
\hline Establishing class rules and routines & 100 & 4.78 & 0.44 & 93 & 4.43 & 0.65 \\
\hline Developing a positive emotional climate & 100 & 4.56 & 0.53 & 93 & 4.64 & 0.63 \\
\hline Reflective practices for improving teaching & 89 & 4.33 & 1.00 & 93 & 4.36 & 0.63 \\
\hline New viewpoints for teaching & 100 & 4.33 & 0.50 & 93 & 4.43 & 0.65 \\
\hline Ways to improve teaching & 89 & 4.22 & 0.97 & 100 & 4.64 & 0.50 \\
\hline
\end{tabular}

\subsection{Extended Written Responses}

Written responses from mentors and mentees provided further insights into the SCIL pathway. Mentors articulated their responses mainly around the macro level, to illustrate, all mentors explained that the SCIL pathway was beneficial to the education system, as "It is an investment in our profession (long term). It supports our vision of a learning community" (Mentor 2, parenthesis in original) and "to better prepare out future teachers for the challenging time of starting their career in the classroom" (Mentor 4). Most important for the mentee's development was that the pathway "connected the explicit teaching and learning in establishing relationships, expectations and professional judgements at the beginning of the school year" (Mentor 5). These experiences were diverse and opened up prospects of learning about relationship building and understandings about the types of decisions teachers need to make at the beginning of the year. Mentors considered the preservice teacher involvement as much needed assistance for the various tasks they undertake at the beginning of the year, "extra assistance at the start of the year establishing routines is invaluable" (Mentor 3) and "it never hurts to have an extra pair of hands" (Mentor 7). This appeared to be a positive experience for mentors. Indeed, there were no difficulties in finding placements for these mentees, as indicated in one Australian review (HRSCEVT, 2007), as all mentors agreed to take on another preservice teacher the following year because of the multiple benefits for all, as noted by Mentor 4 "benefits are for the preservice teacher, mentor and students".

Mentors welcomed the idea of sharing their "beginning of year" practices with the mentees, as Mentor 2 wrote, "It is healthy to share best practice and open our doors to sharing our learning community and school ethos", and Mentor 1 highlighted "I believe it is better to experience the school environment at the beginning to see the set up, data collection and movement of furniture they would otherwise miss". The SCIL pathway has no preservice teacher assessment, which was also welcomed by these mentors: "to be a part of the class community without the stress of personal assessment" (Mentor 7), and "extra time to ask questions of their mentor teacher is great without the worry of lesson planning and discussions on lessons when on prac" (Mentor 10). Bradbury and Koballa (2008) and Ganser (2006) outline that tensions can arise between the mentor and mentee, in particular tensions about teaching philosophies and the mentor's dual role as confidant and assessor. However, the SCIL pathway was a voluntary program that did not involve assessment, hence, alleviating these pressures from both the mentors and the mentees. Yet, there were two comments from mentors who indicated a potential burden for mentees, for example, "it is a fairly big burden on these [preservice teachers], many of whom hold down jobs" (Mentor 7), though this comment was overridden by the many positive benefits in this voluntary program. 
The preservice teachers mainly responded around the meso and micro levels for learning about teaching in the school. At the meso level, four mentees $(8,10,11,14)$ highlighted that working with teachers through professional development opportunities provided a way to understand and engage with teachers' work, for instance: "work with other teachers (e.g., meetings)" (Mentee 11) and more than half the mentees appreciated the whole-school planning and professional development for teachers during the student-free day before the term commenced, for instance, "whole school planning and PD [professional development] sessions prior to school starting" (Mentee 8). Understanding the school context and school expectations allowed these mentees to understand the parameters of their work, providing them with "diverse experiences in a range of school contexts" (HRSCEVT, 2007, p. 74).

Yet, at the micro level, three mentees $(1,2,8)$ specifically stated their role as a "teacher aide" and "sometimes classroom teacher" (Mentee 8), while a further two outlined their role as a helper, for example, "I was introduced to the class as a helper rather than a student teacher" (Mentee 9). They explained that they undertook a variety of other roles including individual, small group work, and whole class teaching, behaviour management, assessments (running records, vocabulary testing), administrative work (e.g., marking roles), homework, resource preparation, and observation of practices. To illustrate, Mentee 3 wrote "reading groups, maths groups, IEP [individual education program] meetings, classroom setup, buddy class, sight word activities". Masters' (2009) review highlighted the need for more literacy and numeracy in preservice teacher education coursework with connections to the classroom for which the SCIL pathway can go partway to address these recommendations. Four participants $(4,10,11,13)$ specifically highlighted the value of observing the classroom teacher for understanding the teacher's roles and responsibilities, and a further four $(3,5,6,8)$ wrote about involvement with classroom and behaviour management. In addition, other preservice teachers $(3,7,9,14)$ emphasised working with specific students for addressing their learning needs, which presented further diverse experiences towards addressing review recommendations (e.g., HRSCEVT, 2007; Masters, 2009).

The mentees were asked about specific skills they had developed during this pathway. Four mentees $(2,6,11,14)$ mentioned specifically building "teacher-student relationship skills" and, in a related way, four $(1,7,8,14)$ mentioned "getting to know the children". Relationships extended to working with other teachers (mentees 6,11 , 13,14 ), for instance "building relationships with other teachers on a professional level" (Mentee 6). The first few days of the school year were considered as a highlight by nearly half the mentees, who explained that they learnt about "setting up for the year" (Mentee 1), including "preparing physical spaces within the room" (Mentee 12). They claimed they learnt about "implementing behaviour management programs" (Mentee 7) by "setting up routines and procedures with students" (Mentee 14), and understanding "assertiveness with 'problem' students" (Mentee 10). Mentee 9 highlighted the "crucial first few days of how teacher and students react with each other and how the class is set up and rules are set up". Unal and Unal (2009) outline three dimensions of classroom management, namely, (1) instructional management (e.g., procedures, rules and planning), (2) people management with positive teacher-student relationships, and (3) behaviour management with the use of proactive and preventative planning of expected behaviours rather than reactionary measures to misbehaviour. Mentees in this current study appeared to be exposed to each of these dimensions. This also assists in educating preservice teachers about classroom management within their first weeks as a beginning teacher, noted as concerns in reviews (e.g., HRSCEVT, 2007). For instance, in general practicum programs, preservice teachers do not usually observe how teachers initially form a rapport with their students.

Continuing at the micro level and linking closer with Unal and Unal's (2009) dimensions, the mentees recorded achievements during the SCIL pathway with all but one participant focusing on working with students (Mentee 3 wrote her achievements were "still to come"). From the outset, mentees appreciated working with students and having "knowledge of students' abilities" (Mentee 1) for "planning, assessing and teaching" (Mentee 13). Four mentees $(2,8,12,13)$ wrote outlined they understood more about planning for teaching such as "short-term and long-term planning of learning activities" (Mentee 12). They also considered it an achievement in knowing students for behaviour management purposes, for example: "working with challenging students" (Mentee 9) and knowledge of specific students (e.g., "the ASD [Autism Spectrum Disorder] children being comfortable with me" Mentee 2) allowed these preservice teachers to learn about managing students with high-level needs. Figure 1 summarises the macro, meso and micro data associated with the extended written responses.

All mentees in this study valued the pathway and claimed "it should be strongly encouraged as it's highly beneficial" (Mentee 4), particularly for "building confidence and more appropriate knowledge" (Mentee 5). All mentees recorded that, as a voluntary program, the workload was reasonable and realistic. Indeed, "benefits far outweigh extra commitment" (Mentee 14). Surprisingly, all participants except 12 commented they did not require any further support to be involved in the SCIL pathway. Mentee 12 brought forward possible 
improvements to the pathway, to illustrate: "site coordinator to ensure SCIL learning guidelines are being met (to ensure against work overload)" (parenthesis in original). There was a section that prompted for advice to enhance the SCIL pathway, which was mainly focused on "making it compulsory" (Participant 1) as a "standard part of the course and not an option" (Participant 9), and up-skilling some of the teachers (e.g., "teachers need to be mentoring the students" Participant 3). In giving advice to the mentor teachers, there were various comments around explicit de-construction of actions to make these more understandable for the mentees, for instance: "teachers to be proactive in explaining how and why they do certain things" (Mentee 10). Similar to any effective mentoring program, mentors in their positions of power needed "to illuminate expectations" to their mentees (Bradbury \& Koballa, 2008, p. 2143); yet as the SCIL pathway was intended to not impact on teacher's workloads, such expectations are intended to ease teachers" workloads by having an "extra hand" in the classroom.

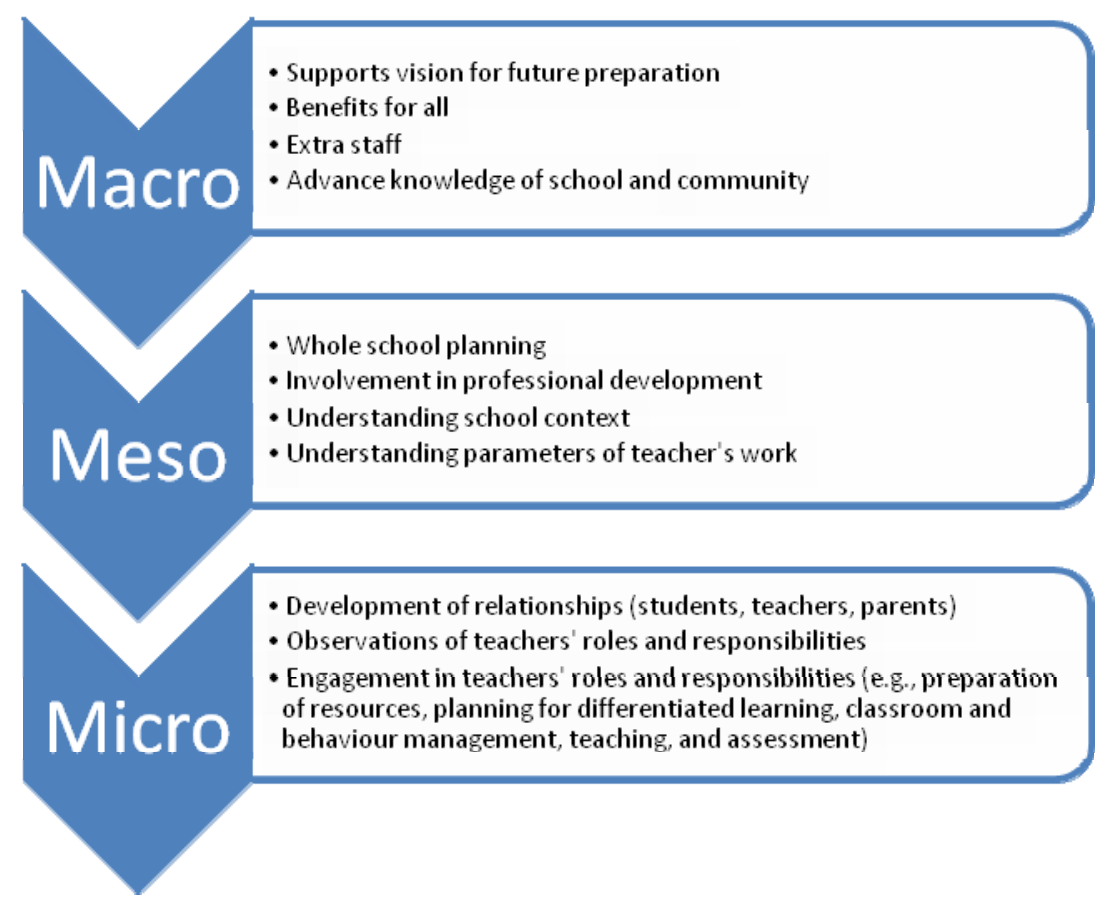

Figure 1. Hierarchical summary of extended written responses at macro, meso, and micro levels

\section{Conclusion}

There are calls for new models of preservice teacher education (HRSCEVT, 2007; Moore, 2003). The SCIL pathway breaks away from tradition models of teacher education (e.g., Graham \& Thornley, 2000), as a voluntary program where final-year preservice teachers were assigned to a class within a school to work with the classroom teacher without the pressure of assessment. They commenced school experiences from day one of the school year, which involved understanding what occurs on the student-free day before students arrive in the classrooms. They observed and participated in the professional development that occurs for teachers, whole school planning, and setting up classrooms in preparation of students' arrivals. These preservice teachers indicated a sense of purpose around the multitude of teacher activities within the school and were privy to establishing behaviour management schemes, setting up of reading groups, and observations of teaching strategies that can be employed to create a positive learning environment at the beginning of the year. Although investigating gestalts (cognitive, emotional, and motivational aspects) would require another study, these preservice teachers had extended experiences, including "one-on-one tutoring, small group work, and other forms of scaffolded development" (Korthagen, 2009; p. 12). Masters (2009) claims that "beginning teachers should be familiar with, and be beginning to develop, a repertoire of evidence-based teaching strategies (e.g., for the teaching of reading)" (p. 9), which provides opportunities for these final-year preservice teachers, who are in line to become beginning teachers the following year.

As an extension model for advancing teacher education, the SCIL pathway appeared to offer a supportive 
learning environment for the preservice teachers to engage in practices that may not be available during practicum experiences. These mentees were able to observe mentors develop relationships with students, colleagues and parents at the beginning of the year. Relationships are central to teaching (Pianta, Hamre, \& Allen, 2012) and the SCIL pathway provided a context for fostering positive relationships, which is also recognised as a way to retain teachers in schools (Waddell, 2010). Indeed, a variable contributing to predicting beginner teacher burnout is the "lack of collaborative and supportive ambience" (Gavish \& Friedman, 2010) for which SCIL may commence forming ideas for greater collaboration. The sample size was a limitation to this small-scale study and further research needs to include other qualitative research methods such as interviews and observations of practice. Indeed, a quasi-experimental design to measure differences between SCIL pathway preservice teachers and those undertaking general coursework may assist to specify the distinctions between preservice teachers' development in each model. As a cost-effective model, the SCIL pathway seemed to address some gaps that appear in general practicum and internship models.

\section{Acknowledgements}

This work was conducted within the Teacher Education Done Differently (TEDD) project funded by the Australian Government Department of Education, Employment and Workplace Relations (DEEWR). Any opinions, findings, and conclusions or recommendations expressed in this paper are those of the authors and do not necessarily reflect the views of the DEEWR. We would like to acknowledge the work of Dr Michelle Murray as the research assistant.

\section{References}

Blair, D. V. (2008). Mentoring novice teachers: Developing a community of practice. Research Studies in Music Education, 30(2), 99-117.

Bradbury, L. U., \& Koballa, T. R., Jr. (2008). Borders to cross: Identifying sources of tension in mentor-intern relationships. Teaching and Teacher Education: An International Journal of Research and Studies, 24(8), 2132-2145.

Bradley, D., Noonan, P., Nugent, H., \& Scales, B. (2008). Review of Australian higher education: Final report. Canberra: Australian Government.

Brady, L. (2000). Directions and priorities in teacher education. Australian Journal of Teacher Education, 25(1), $1-9$.

Briscoe, C., \& Peters, J. (1997). Teacher collaboration across and within schools: Supporting individual change in elementary science teaching. Science Teacher Education, 81(1), 51-64.

Canter, L., \& Canter, M. (1997). Assertive discipline positive behavior. Santa Monica, CA: Lee Canter \& Associates.

Committee for the Review of Teacher Education. (2003). Australia's teachers: Australia's future: Advancing innovation science, technology and mathematics. Agenda for action. Canberra: Commonwealth of Australia.

Commonwealth of Australia. (2007). Top of the class: Report on the inquiry into teacher education. Retrieved from http://www.curriculum.edu.au/leader/top_of_the_class,18080.html?issueID=10733 (June 30, 2009)

Coombe, K. (1989). The mentor system. Independent Education, 19(4), 24-26.

Creswell, J. W. (2012). Educational research: Planning, conducting, and evaluating quantitative and qualitative research (4th ed.). Upper Saddle River, NJ: Pearson Education Inc.

Darling-Hammond, L. (1991). Are our teachers ready to teach? Quality Teaching, 1(1), 6-7.

Deng, Z. (2004). The role of theory in teacher preparation: An analysis of the concept of theory application. Asia-Pacific Journal of Teacher Education, 32(2), 143-157.

Ganser, T. (1996). What do mentors say about mentoring? Journal of Staff Development, 17(3), 36-39.

Ganser, T. (2002). How teachers compare the roles of cooperating teacher and mentor. Educational Forum, 66(4), 380-385.

Giebelhaus, C. R., \& Bowman, C. L. (2002). Teaching mentors: Is it worth the effort? Journal of Educational Research, 95(4), 246-254.

Glasser, W. (1992). The quality school: Managing students without coercion. New York: Harper \& Row.

Graham, S., \& Thornley, C. (2000). Connecting classrooms in pre-service education: Conversations for learning. 
Asia-Pacific Journal of Teacher Education, 28(3), 235-245.

Hittleman, D. R., \& Simon, A. J. (2006). Interpreting educational research: An introduction for consumers of research. Upper Saddle River, NJ: Prentice-Hall.

Hodge, S. R., Davis, R., Woodward, R., \& Sherrill, C. (2002). Comparison of practicum types in changing preservice teachers' attitudes and perceived competence. Adapted Physical Quarterly, 19(1), 155-171.

House of Representatives Standing Committee on Educational and Vocational Training [HRSCEVT]. (2007). Top of the class: Report on the inquiry into teacher education. Canberra: The Parliament of the Commonwealth of Australia.

Hudson, P., \& Hudson, S. (2006, November). Initiating community engagement for enhancing preservice teacher education. In Proceedings of the EDU-COM 2006 International Conference, Engagement and empowerment: New opportunities for growth in higher education. [CD ROM]: Edith Cowan University; Khon Kaen University; Bansomdejchaopraya Rajabhat University, Bangkok, Thailand.

Hudson, P. (2007). Examining mentors' practices for enhancing preservice teachers' pedagogical development in mathematics and science. Mentoring \& Tutoring: Partnership in Learning, 15(2), 201-217.

Hudson, P., \& Hudson, S. (2011). Partners in education: The Teacher Education Done Differently (TEDD) project. Paper presented at the Australian Teacher Educators Association (ATEA), Melbourne.

Hudson, P., \& Hudson, S. (2012). Examining preservice teachers' applied learning experiences in the Teacher Education Done Differently (TEDD) project. Teacher Education and Practice, 25(3), 421-440.

Hudson, P., Skamp, K., \& Brooks, L. (2005). Development of an instrument: Mentoring for effective primary science teaching. Science Education, 89(4), 657-674.

Hudson, S. (2009). Preservice teacher perceptions of the confidence to teach in the middle school context. International Journal of Learning, 16(1), 1-12.

Hudson, S., \& Hudson, P. (2008). Devising university-based programs for the wider educational community. Paper presented at the Paris International Conference on Education, Economy \& Society, Paris, France.

Hunt, D., \& Michael, C. (1983). Mentorship: A career training and development tool. Academy of Management Review, 8(3), 475-485.

Jones, F. (2007). Tools for teaching. Santa Cruz, CA: Frederick H. Jones \& Associates, Inc.

Korthagen, F. A. J., \& Kessels, J. P. A. M. (1999). Linking theory and practice: Changing the pedagogy of teacher education. Educational Researcher, 28(4), 4-17.

Korthagen, F., Loughran, J., \& Russell, T. (2006). Developing fundamental principles for teacher education programs and practices. Teaching and Teacher Education, 22, 1020-1041.

Kounin, J. (1977). Discipline and group management in classrooms. Huntington, NY: R. E. Krieger.

Lunenberg, M., \& Korthagen, F. (2009). Experience, theory, and practical wisdom in teaching and teacher education. Teachers and Teaching: Theory and Practice, 15(2), 225-240.

Masters, G. N. (2009). A shared challenge: Improving literacy, numeracy and science learning in Queensland primary school. Camberwell, Victoria: Australian Council for Educational Research.

Moore, R. (2003). Reexamining the field experiences of preservice teachers. Journal of Teacher Education, 54(1), 31-42.

Newby, T., \& Heide, A. (1992). The value of mentoring. Performance Improvement Quarterly, 5(4), 2-15.

Pianta, R. C., Hamre, B. K., \& Allen, J. P. (2012). Teacher-student relationships and engagement: Conceptualizing, measuring, and improving the capacity of classroom interactions. In S. L. Christenson, A. L. Reschly \& C. Wylie (Eds.), Handbook of research on student engagement, (pp. 365-386). US: Springer.

Putman, S. M. (2009). Grappling with classroom management: The orientations of preservice teachers and impact of student teaching. The Teacher Educator, 44(4), 232-247.

Ramsey, G. (2000). Quality matters: Revitalising teaching: critical times, critical choices. Sydney, NSW: NSW Department of Education and Training.

Riggs, I. M., \& Sandlin, R. A. (2002). Professional development of mentors within a beginning teacher induction program: How does the garden (mentors) grow? Paper presented at the annual meeting of the Educational Research Association, New Orleans, LA. 
Smith, K., \& Snoek, M. (1996). Dutch and Israel student teachers' views on their future roles as teachers. Paper presented to the Annual Association of Teacher Education in Europe, Glasgow, Scotland.

Snowman, J., Dobozy, E., Scevak, J., Bryer, F., Bartlett, B., \& Biehler, R. (2009). Psychology: Applied to teaching. Milton, Qld: John Wiley \& Sons.

Tobias, S. (1999). Some recent developments in teacher education in mathematics and science: A review and commentary. Journal of Science Education and Technology, 8, 21-31.

Unal, Z., \& Unal, A. (2009). Comparing beginning and experienced teachers' perceptions of classroom management. The Educational Forum, 73(3), 256-270.

Upson, L., Koballa, T., \& Gerber, B. (2002). Preparing science specific mentors: A look at one successful Georgia program. In Proceedings of the Annual International Conference of the Association for the Education of Teachers in Science, Charlotte, NC.

Victorian Parliament, Education and Training Committee. (2005). Step up, step in, step out: Report on the inquiry into the suitability of pre-service teacher training in Victoria. Melbourne: Victorian Government Printer.

Vinson, T. (2004). Inquiry into the provision of public education in NSW. Retrieved from http://www.plutoaustralia.com/p1/default.asp?pageId=317 (October 8, 2009)

Waddell, J. H. (2010). Fostering relationships to increase teacher retention in urban schools. Journal of Curriculum and Instruction, 4(1), 70-85.

Wideen, M., Mayersmith, J., \& Moon, B. (1998). A critical analysis of the research on learning to teach-making a case for an ecological perspective on inquiry. Review of Educational Research, 68(130).

Zeichner, K. (2010). Rethinking the connections between campus courses and field experiences in college- and university-based teacher education. Journal of Teacher Education, 61(1-2), 89-99. 